\title{
INFLUENCE OF CUBE AND CUBIPOD ARMOR POROSITIES ON OVERTOPPING
}

\author{
Jorge Molines ${ }^{1}$, Tomas Javier Perez, Guillermo Zarranz and Josep Ramon Medina
}

This paper describes a series of small-scale tests which examined the influence of armor porosity on overtopping. The cube and Cubipod armored models corresponded to the Punta Langosteira Breakwater (A Coruña, Spain) during construction, when the primary layer is not in place and the crest freeboard is much lower. Overtopping rates for incomplete cross sections (those under construction) differed significantly from completed ones. After analyzing the variables influencing overtopping, new formulas were developed to estimate overtopping rates in a section during construction. Both the conventional $\mathrm{Rc} / \mathrm{H}_{\mathrm{m} 0}$ and the ratio $\mathrm{Rc} / \mathrm{d}$ had a significant influence on overtopping rates of complete and incomplete cross sections.

Keywords: rubble-mound breakwater; armor porosity; overtopping; Cube; Cubipod; construction stage.

\section{INTRODUCTION}

Mound breakwater performance is affected by armor porosity, which is known to increase or decrease reflection coefficient, hydraulic stability, run-up and overtopping. Mound breakwaters are designed with a nominal porosity but real armor layers are constructed under unfavorable conditions (blind underwater placement, wave climate, construction grid, etc.). This means that real armor porosity is higher than the nominal value considered in the design process. Armor layer porosity is thus a critical design variable that may lead to budget deviations and uncontrolled structural risks (see Medina et al., 2010). High overtopping rates can create hazardous conditions for workers, equipment and pedestrians and can even result in the complete breakwater failure (see Aminti and Franco, 1988). Therefore, the influence of $\mathrm{p} \%$ on overtopping is relevant for both theoretical as well as practical purposes.

Shankar and Jayaratne (2003) concluded that in the case of rubble mound breakwaters armor porosity had no effect on run-up. In fact, none of the overtopping formulas given in the EurOtop Manual (2007) explicitly include armor porosity as a variable. Much research has been carried out for crownwalled mound breakwaters considering only one armor porosity ( $\mathrm{p} \%$ ) for each CAU. Bruce et al. (2009) developed overtopping studies using concrete armor units (CAUs) but considering only one porosity for each CAU. Conventional overtopping tests use models with complete cross sections corresponding to designed breakwaters: the primary armor layer is in place and the model has a relatively high crest freeboard. However, yet little attention has been given to breakwater sections under construction.

In this research, the influence of armor porosity on the overtopping rates is studied for cube and Cubipod armored breakwaters during construction when the primary armor layer is not in place and the crest freeboard is very low. Like the conventional cube, the Cubipod (see Gómez-Martín and Medina, 2007) is a CAU which not only offers high structural resistance, easy placement and high hydraulic stability but thanks to the protrusion-faced design, it also significantly reduces heterogeneous packing within the armor by increasing the friction with the secondary layer. Moreover, as a Cubipod layer is rougher than a conventional cube layer, a Cubipod-armored mound breakwater can reduce run-up, overtopping and wave forces on crown walls (see Figure 1). In this study, small-scale cube and Cubipod armored 2D breakwater models (see Smolka et al., 2009) are tested in a wave flume, measuring both hydraulic stability and overtopping for an incomplete cross section, which is considered here as representative of a breakwater under construction.

\footnotetext{
${ }^{1}$ Laboratory of Ports and Coasts, Universitat Politècnica de València, Camino de Vera s/n, Valencia, 46021, Spain
} 


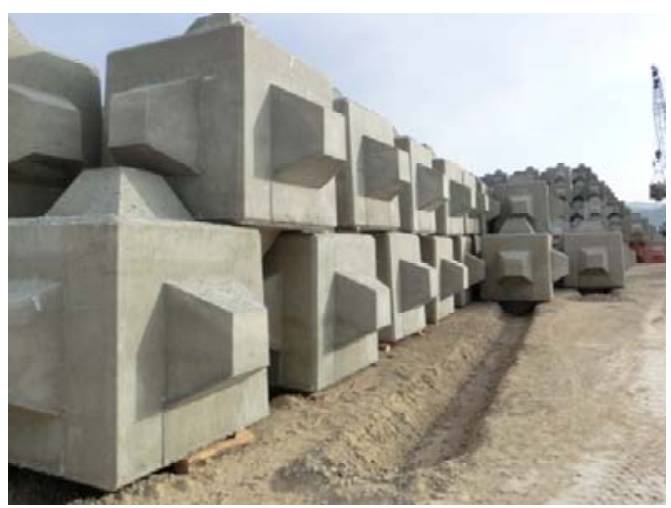

Figure 1. The Cubipod.

\section{TECHNICAL BACKGROUND}

Shankar and Jarayatne (2003) studied run-up on a quarrystone armored breakwater with three porosities $(30.4 \%, 51.3 \%$ and $53.8 \%)$ and in this case, the SPM (1984) specifications for smooth and roughness slope correctly estimated the run-up, which increased as wave steepness decreased, especially on smooth slopes. By analyzing structural variables such as roughness factor, armor porosity or layer thickness and hydraulic variables such as Iribarren's number, steepness or wave height, they concluded that the influence of armor roughness on run-up was more relevant than that of armor porosity.

The EurOtop Manual (2007) provided a formula to estimate overtopping on armored breakwaters (see Equation 1). This formula does not explicitly consider porosity as a variable, its influence being assumed by the roughness factor $\left(\gamma_{f}\right)$ for each CAU:

$$
\frac{q}{\sqrt{g \cdot H_{m 0}^{3}}}=0.2 \cdot \exp \left(-2.6 \cdot \frac{R_{c}}{H_{m 0} \cdot \gamma_{f} \cdot \gamma_{\beta}}\right)
$$

where $\mathrm{q}$ is the mean overtopping discharge; $\mathrm{Rc}$ is the crest freeboard; $\mathrm{H}_{\mathrm{m} 0}$ is the significant wave height; $g$ is the gravity acceleration; $\gamma_{f}$ is the roughness factor, and $\gamma_{\beta}$ is the wave obliquity factor.

Bruce et al. (2009) conducted tests to establish the influence of armor type and configuration on overtopping. Roughness factors $\gamma_{f}$ were determined for rock (2 layers), cube (1 and 2 layers), Tetrapod, Antifer, Haro, Accropode, Core-Loc and Xbloc. These roughness factors were included in the CLASH database (http://www.clash-eu.org). These researchers concluded that the breaker parameter $\xi_{m-1,0}$ had little influence on overtopping. Table 1 specifies the characteristics of the armors analyzed by Bruce et al. (2009), who tested only one armor porosity for each CAU. In the present paper, armor porosity $\mathrm{p} \%$ is considered as $\mathrm{p} \%=100 \%-\mathrm{k}_{\mathrm{t}}[1-$ Porosity $(\%)]$ (see Medina et al., 2010).

\begin{tabular}{|l|cc|c|c|c|c|}
\hline \multicolumn{2}{|l|}{ Table 1. Porosities for armor units tested by Bruce et al. (2009) } \\
\hline Type of armor & $\begin{array}{l}\text { p\%(Medina } \\
\text { al. 2010) }\end{array}$ & No. of layers & $\begin{array}{l}\text { Layer thickness } \\
\text { coeff. kt }\end{array}$ & Porosity (\%) & $\begin{array}{l}\text { Packing density, } \\
\Phi\end{array}$ \\
\hline Rock & $31 \%$ & 2 & 1.15 & $\approx 40$ & 1.38 \\
Cube & $42 \%$ & 2 & 1.1 & 47 & 1.17 \\
Antifer & $42 \%$ & 2 & 1.1 & 47 & 1.17 \\
Tetrapod & $48 \%$ & 2 & 1.04 & 50 & 1.04 \\
Dolosse & $59 \%$ & 2 & 0.94 & 56 & 0.83 \\
Cubes (1layer) & $30 \%$ & 1 & & & \\
Accropode & $38 \%$ & 1 & 1.0 & 30 & 0.70 \\
Core-Loc & $44 \%$ & 1 & 1.51 & 59 & 0.62 \\
Xbloc & $42 \%$ & 1 & 1.49 & 63 & 0.56 \\
\hline
\end{tabular}




\section{EXPERIMENTAL METHODOLOGY}

2D small-scale tests were carried out in the wind and wave flume $(30 \times 1.2 \times 1.2 \mathrm{~m})$ of the Laboratory of Ports and Coasts at the Universitat Politècnica de València (UPV). The experiments aimed to evaluate the influence of armor porosity on overtopping rates. The tested cross section represented the Punta Langosteira Breakwater (A Coruña, Spain) during construction at a 1:46 scale (see Figure 2). Two armors were tested: two layers of cubes and two layers of Cubipods, both placed randomly. Three porosities were tested for cubes $(37 \%, 41 \%$ and $46 \%)$ and two porosities were tested for Cubipods (37\% and $42 \%$ ).

Two water depths were considered $\left(\mathrm{d}_{\mathrm{HWL}}[\mathrm{m}]=45\right.$ and $\left.\mathrm{d}_{\mathrm{LWL}}[\mathrm{m}]=40.0\right)$, each depth being tested with both regular (calibration) and irregular waves (JONSWAP, $\gamma=3.3, \mathrm{~N}=1000$ waves) until Inititation of Destruction (IDe) or massive overtopping. Tests were conducted increasing $\mathrm{H}_{\mathrm{m} 0}$ and Tp to maintain approximately constant the Iribarren number $\left(\operatorname{Irp}=\operatorname{Tp} \cdot \tan (\alpha) /\left(2 \pi \mathrm{H}_{\mathrm{m} 0} / \mathrm{g}\right)^{0.5}=3,4\right.$ and 5). Eight wave gauges measured the characteristics of the incident waves. Incident and reflected waves were separated using the LASA-V method (see Figueres and Medina, 2004), allowing wave separation of non-linear and non-stationary waves. Overtopping discharges were measured by weighing the increment in the mass of water in the collection tank during the test. Comparing the photographs taken perpendicular to the slope before and after each test, the damage was measured following the Virtual Net Method (see Gómez-Martín and Medina, 2006).

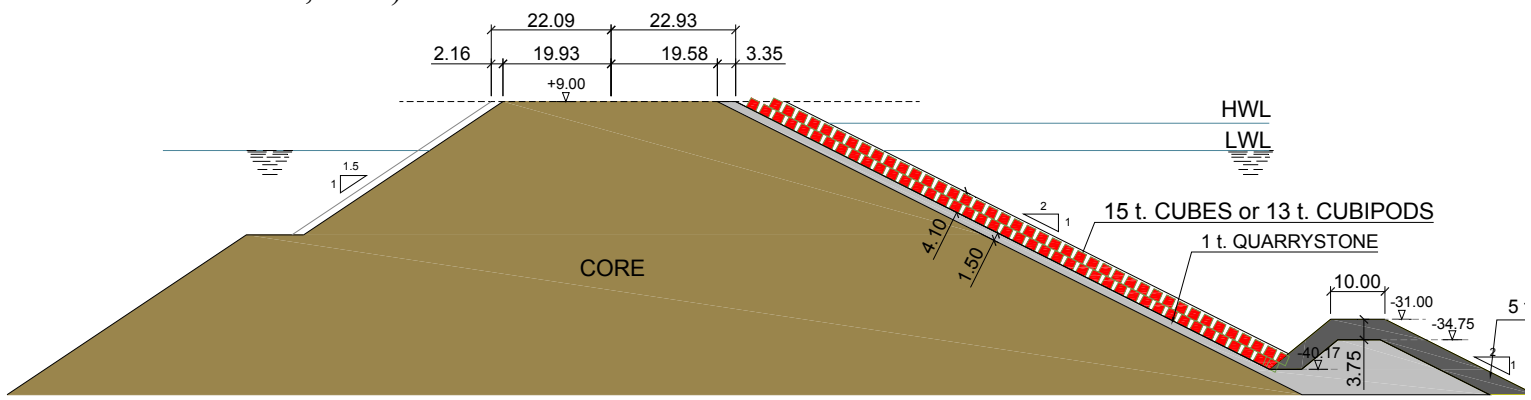

Figure 2. Punta Langosteira Breakwater cross section during construction.

\section{DATA ANALYSIS AND RESULTS}

Conventional overtopping formulas are usually based on the variables $\mathrm{Rc} / \mathrm{H}_{\mathrm{m} 0}$ and Iribarren's number; $\mathrm{Rc} / \mathrm{H}_{\mathrm{m} 0}$ is widely accepted as the basic variable to estimate overtopping rates. Most research focuses on overtopping in complete breakwater cross sections, which present low damage and porosities near $40 \%$. However, armor porosities and incomplete breakwater cross sections have not yet received adequate attention in overtopping literature. During construction, the primary layer is not in place and the final crest freeboard is not achieved. In the construction stage, the variables Rc/d and $\mathrm{Rc} / \mathrm{Dn}$ are beyond the usual range, so these two variables may indeed influence overtopping. To this end, tests at the UPV were carried out with different porosities, and results indicated armor damage was high in many cases. For the UPV tests, the variables Rc/d, Rc/Dn, porosity (p\%) and armor damage were added to $\mathrm{Rc} / \mathrm{Hm} 0$ and $\xi_{p}$ to calculate the overtopping rates in sections under construction. The wind $U[\mathrm{~m} / \mathrm{s}]$ was also considered as an input in the model when pertinent (only cubes were tested under wind/wave conditions).

Minimum and maximum porosities ( $\mathrm{p} \%=37 \%$ and $46 \%$ ) are given in Figures 3 and 4, respectively, which compare the UPV tests with results from Bruce et al. (2009) for cubes placed following an irregular pattern. The results reported by Bruce et al. (2009) were based on EurOtop (2007) formula for a conventional cube armored breakwater with a 2:1 slope, similar to the model tested at the UPV. UPV tests are represented by colored dots and grouped by Iribarren's numbers (dot shapes).

On the one hand, as observed in Figure 3, tests conducted with LWL (Low Water Level) present $\mathrm{Rc} / \mathrm{d}=0.22$, a value similar to the range of [0.26 to 0.56] given by Bruce et al. (2009). However, $\mathrm{Rc} / \mathrm{Dn}=4.9$ is much higher than the usual range [2.2 to 3.5] cited by Bruce et al. (2009). On the other hand, tests conducted with HWL present $\mathrm{Rc} / \mathrm{d}=0.09$, much lower than the usual values for complete cross sections. Thus, Rc/d in the section under construction is beyond the usual range, and both the conventional dimensionless freeboard $\left(\mathrm{Rc} / \mathrm{H}_{\mathrm{m} 0}\right)$ and the parameter $\mathrm{Rc} / \mathrm{d}$ appear to influence the overtopping rates. Consequently, armor porosity seems to have some influence on overtopping (see Figure 4). Armor layers with high porosity are heavily damaged in LWL and present high overtopping rates in HWL (High Water Level); however, when armor porosity is lower $(37 \%<\mathrm{p} \%<41 \%)$, there is 
little armor damage and the overtopping rates are similar to armors with no damage. As expected, in both cases ( $\mathrm{p} \%=37 \%$ and $46 \%$ ), $\mathrm{Rc} / \mathrm{H}_{\mathrm{m} 0}$ and Iribarren's number confirm a relevant influence on the overtopping rates. Surprisingly, the ratio Rc/d also suggests a clear influence on the overtopping discharges; armor damage may be different since secondary layers of an incomplete cross section are much deeper than primary layers on a typical complete breakwater section.

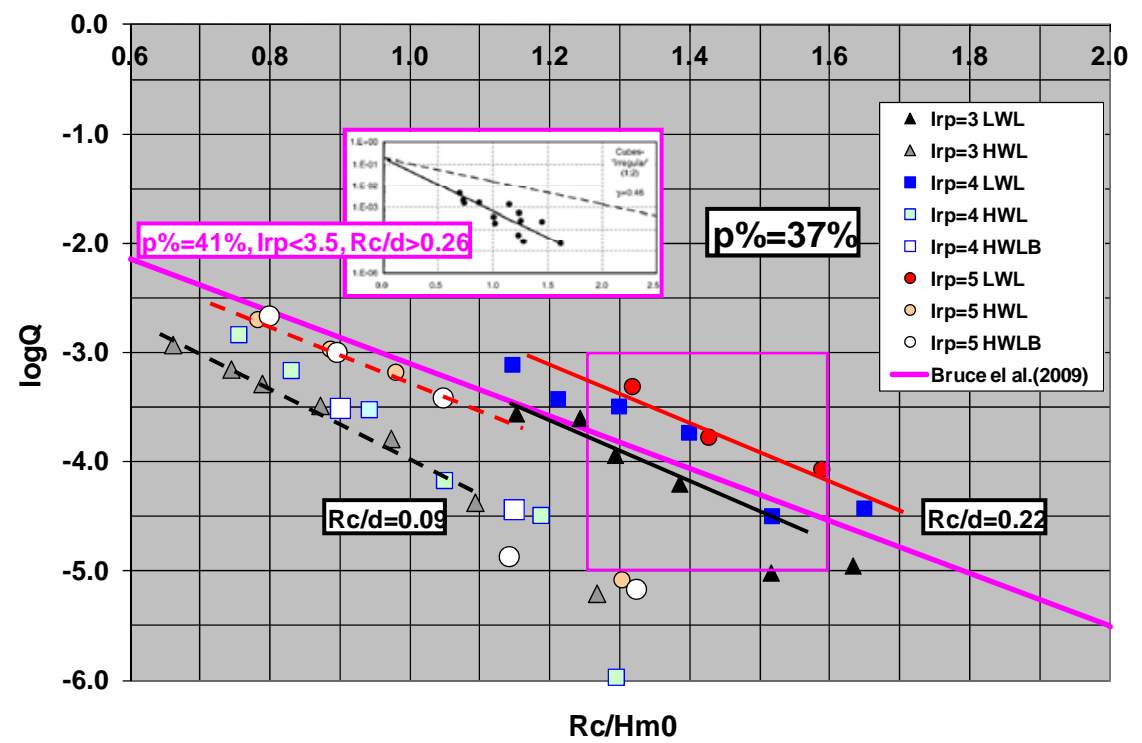

Figure 3. Overtopping discharges from UPV tests ( $p \%=37$ ) compared with those given by Bruce et al. (2009).

Furthermore, the white squares and circles (see Figure 3) represent special tests without reconstruction (HWL tests after LWL tests). The $37 \%$ porosity presents similar overtopping results for both HWL tests after LWL and HWL tests with reconstructed armor. In contrast, when the porosity is high (46\% in Figure 4), armor damage and overtopping are much greater. The white triangles in Figure 4 reflect the HWL tests after LWL. The damage, $D \approx 11$, seems to be responsible for the one order of magnitude increase in the overtopping rates.

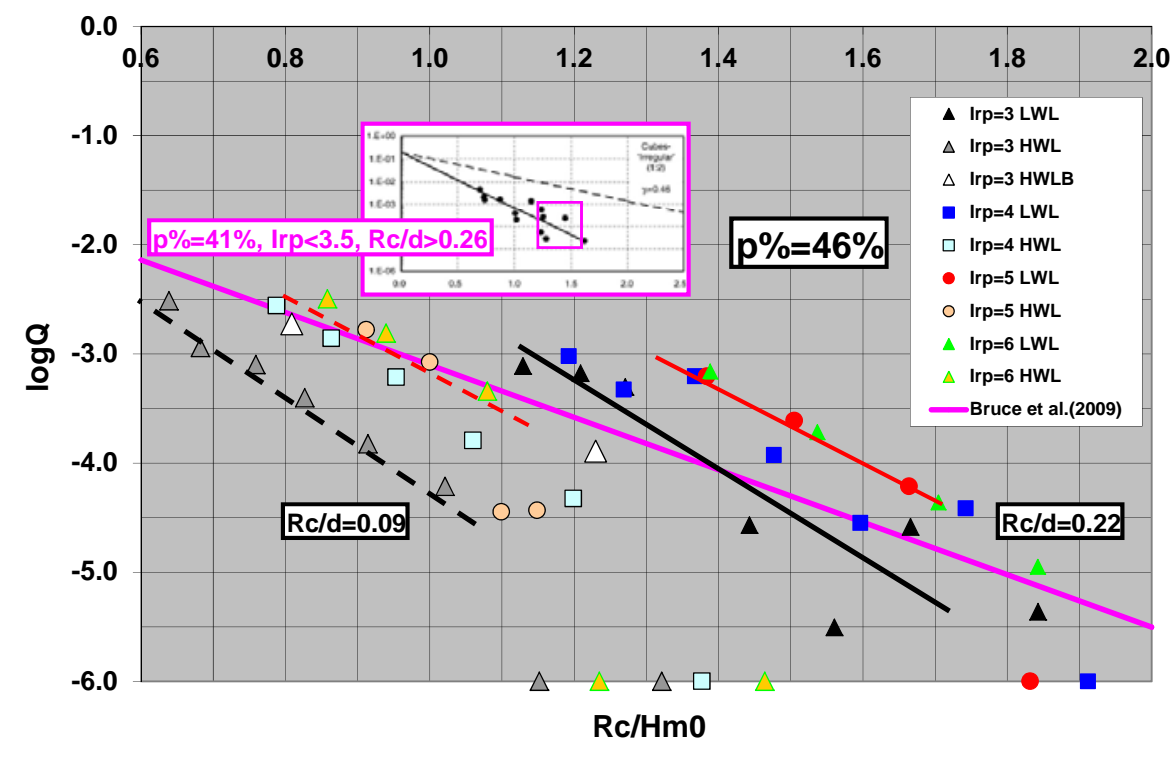

Figure 4. Overtopping discharges from UPV tests $(p \%=46)$ compared with those given by Bruce et al. (2009). 
In brief, overtopping on a section during construction should be governed by the following variables: Rc/Hm0, Irp, Rc/Dn, Rc/d, porosity (p\%), armor damage and $\mathrm{U}[\mathrm{m} / \mathrm{s}]$. Thus, overtopping rates for an incomplete section might follow a generic model similar to that proposed by Medina et al. (2002):

$$
Q=\frac{q}{\sqrt{g H_{m 0}^{3}}}=A \times \exp \left(a * \operatorname{Irp}+b^{*} p \%+c * U+d * \frac{R c}{d}+e * \frac{R c}{H_{m 0}}+f * \text { damage }\right)
$$

where $\{\mathrm{A}, \mathrm{a}, \mathrm{b}, \mathrm{c}, \mathrm{d}, \mathrm{e}, \mathrm{f}\}$ are the model parameters; $\mathrm{q}$ is the mean overtopping discharge; $\mathrm{Q}$ is the non dimensional overtopping rate; Irp is the Iribirren number (calculated with $\mathrm{Tp}$ and $\mathrm{Hm} 0$ ); $\mathrm{p} \%$ is the armor porosity; $\mathrm{U}[\mathrm{m} / \mathrm{s}]$ is wind velocity in the flume; $d$ is the armor depth; Rc is the crest freeboard and $\mathrm{H}_{\mathrm{m} 0}$ is the significant wave height.

\section{Cube armored breakwater}

Results from the first t-student analysis (with $\alpha=5 \%$ ) of the measured overtopping discharges for cube armors indicated that neither the porosity $(\mathrm{p} \%)$ nor the armor damage were significant. The fitting goodness was evaluated by the Relative Mean Square Error:

$$
R M S E=\frac{M S E}{V a r}
$$
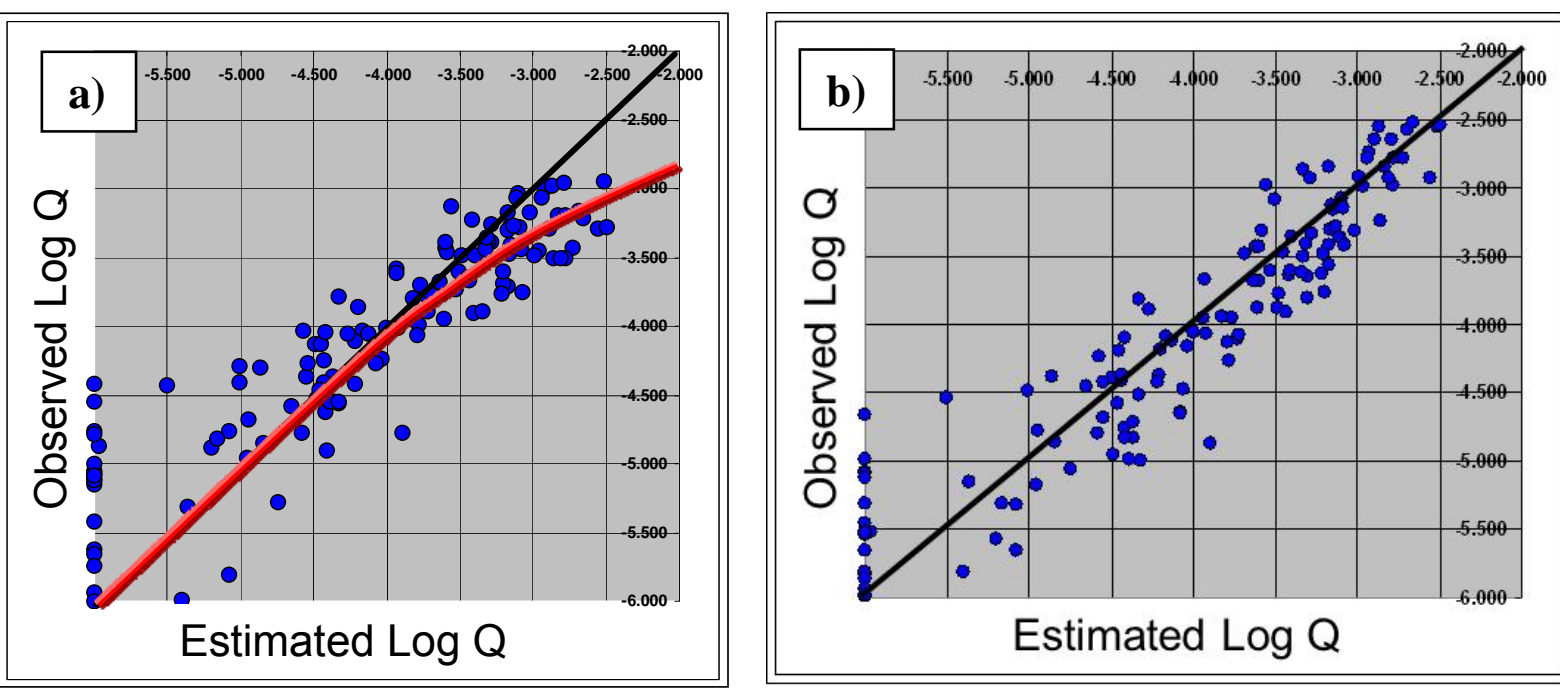

Figure 5. Cross validation graphs for cubes: (a) first statistical model and (b) final model.

Figure 5a represents the cross validation graph after the first statistical analysis with RMSE $=0.25$. The red line reflects a non-linear tendency, so the interactions among variables were studied to explain this relationship. After examining all the interactions, two were found to be the most influential, so the statistical analysis was repeated adding both non-linear interactions (see Equation 4), and the RMSE decreased until 0.14 (Figure 5b).

$Q=\frac{q}{\sqrt{g H_{m 0}^{3}}}=A \times \exp \left(a * \operatorname{Irp}+b^{*} p \%+c * U+d * \frac{R c}{d}+e * \frac{R c}{H_{m 0}}+f *\right.$ damage $\left.+g * \frac{R c}{H_{m 0}} * \operatorname{Irp}+h * \frac{R c}{H_{m 0}} * \frac{R c}{d}\right)$

In this case, the porosity ( $\mathrm{p} \%$ ) was eliminated and the final model was:

$Q=\frac{q}{\sqrt{g H_{m 0}^{3}}}=A b * \exp \left(a b *(\operatorname{Irp}-3)+c b * U-d b *\left(\frac{R c}{d}-0.25\right)-e b * \frac{R c}{H_{m 0}}+f b^{*} D-g b * \frac{R c}{H_{m 0}} * \operatorname{Irp}+h b^{*} \frac{R c}{H_{m 0}} * \frac{R c}{d}\right)$

where $\mathrm{Ab}=4.8010^{-3} ; \mathrm{ab}=2.17 ; \mathrm{cb}=0.23 ; \mathrm{db}=36.3 ; \mathrm{eb}=11.5 ; \mathrm{fb}=0.12 ; \mathrm{gb}=1.15$ and $\mathrm{hb}=48.8$. $\mathrm{Q}$ is the non-dimensional overtopping; $\mathrm{q}[\mathrm{m} 3 / \mathrm{s} / \mathrm{m}]$ is the mean overtopping discharge; $\mathrm{g}[\mathrm{m} / \mathrm{s} 2]$ is the gravity acceleration; $\operatorname{Irp}=(\tan \alpha) /\left(\mathrm{H}_{\mathrm{m} 0} / \mathrm{Lp}\right)^{0.5}$ is the Iribarren number calculated using $\mathrm{Tp}$ and $\mathrm{H}_{\mathrm{m} 0}$; $\mathrm{Rc}$ is the crest freeboard; $\mathrm{H}_{\mathrm{m} 0}$ is the significant wave height at the breakwater toe; $\left.\left.\mathrm{U}\right] \mathrm{m} / \mathrm{s}\right]$ is the wind velocity in the flume; $d$ is the depth at the breakwater toe, and $\mathrm{D}$ is the non-dimensional damage evaluated using the Virtual Net Method (see Gómez-Martín and Medina, 2006).

The range of the variables for Equation 5 to estimate the overtopping on cube armored breakwaters during construction is given in Table 2 . 


\begin{tabular}{|l|l|l|}
\hline \multicolumn{3}{|c|}{ Table 2. Range of variables for cube overtopping formula. } \\
\hline Variable & Minimum & Maximum \\
\hline Rc/Hm0 & 0.639 & 2.667 \\
Irp & 2.989 & 6.302 \\
Rc/d & 0.090 & 0.225 \\
U[m/s] & 0.000 & 7.000 \\
damage & 0.000 & 20.000 (Destruction) \\
\hline
\end{tabular}

\section{Cubipod armored breakwater}

The Cubipods were analyzed analogously to the cubes, but the armor damage to the Cubipod armored breakwater model was much lower $(\mathrm{W}[\mathrm{t}]=13$ Cubipods are much more stable than $\mathrm{W}[\mathrm{t}]=15$ cubes). After the first t-student analysis (with $\alpha=5 \%$ ), neither the armor porosity (p\%) nor the damage (D) were significant. The RMSE (Equation 3) was 0.30, and the cross validation graph (see Figure 6a) showed a certain non-linear tendency as in the case of cubes. Therefore, interactions among variables were studied. The proposed model is that corresponding to Equation 4.

In this case, porosity ( $\mathrm{p} \%$ ), damage (D) and Rc/d were eliminated, and the RMSE decreased to 0.16 . The cross validation graph is given in Figure $6 \mathrm{~b}$.
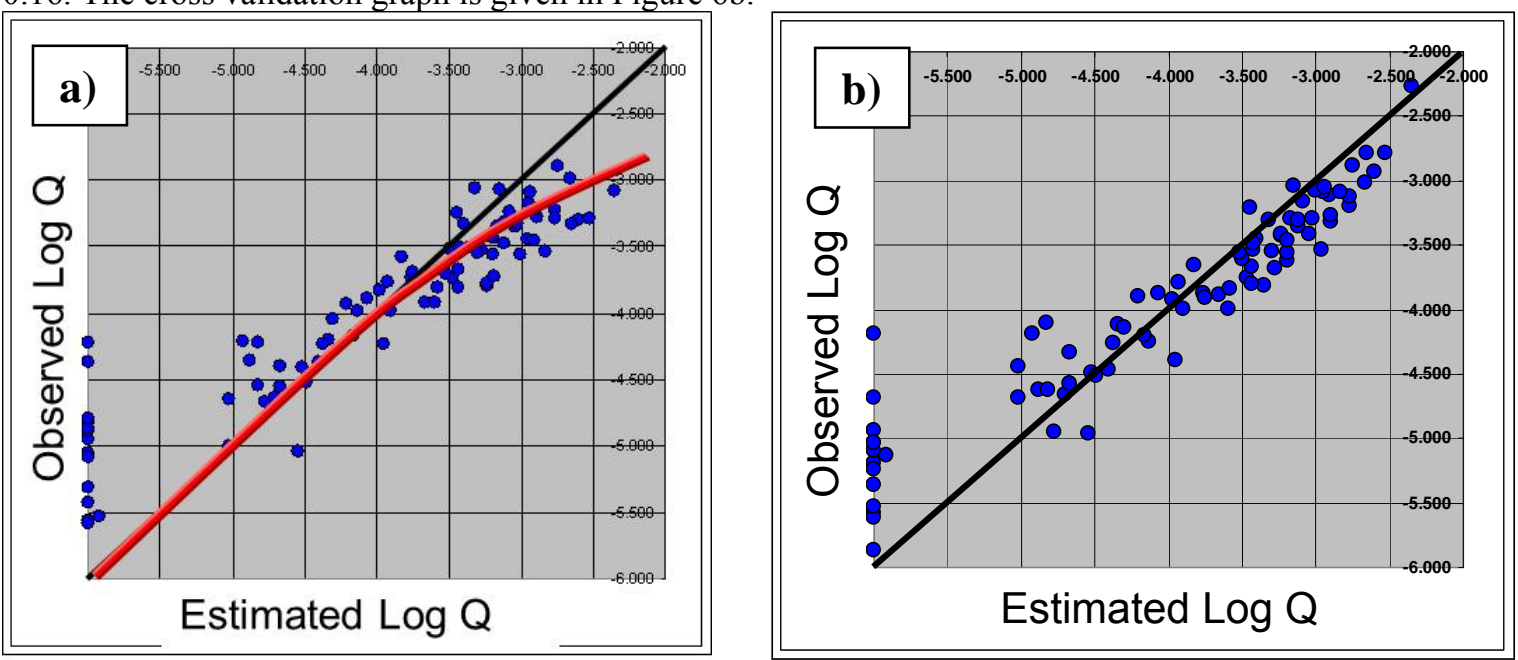

Figure 6. Cross validation graphs for Cubipods:(a) first statistical model and (b) final model.

The final model for Cubipods was:

$Q=\frac{q}{\sqrt{g H_{m 0}^{3}}}=A c * \exp \left(a c *(\operatorname{Irp}-3)-d c *\left(\frac{R c}{d}-0.25\right)-e c * \frac{R c}{H_{m 0}}+f c * D-g c * \frac{R c}{H_{m 0}} * \operatorname{Irp}+h c * \frac{R c}{H_{m 0}} * \frac{R c}{d}\right)$

where $\mathrm{Ac}=13.2010^{-3} ; \mathrm{ac}=2.96 ; \mathrm{dc}=23.8 ; \mathrm{ec}=7.77 ; \mathrm{fc}=0 ; \mathrm{gc}=1.90$ and $\mathrm{hc}=42.9$. The range of the variables for Equation 6 is shown in Table 3 below.

\begin{tabular}{|l|l|l|}
\hline \multicolumn{3}{|c|}{ Table 3. Range of variables for Cubipod overtopping formula. } \\
\hline Variable & Minimum & Maximum \\
\hline Rc/Hm0 & 0.642 & 3.243 \\
Irp & 2.857 & 5.345 \\
Rc/d & 0.090 & 0.225 \\
\hline
\end{tabular}

\section{DISCUSSION}

Comparing the two new overtopping formulas, the only difference found is that the armor damage (D) and the wind (U) influenced overtopping in the case of cubes but not Cubipods. Only the cube armors were damaged while there was less damage on the Cubipod armored breakwater, which was not tested under wind conditions.

Figure 7 compares the application of the new formulas to cube (green line) and Cubipod (orange line) CAUs for incomplete sections and similar conditions. As observed in previous tests, overtopping is lower on the Cubipod armored breakwater, due to the greater armor roughness of this CAU. 


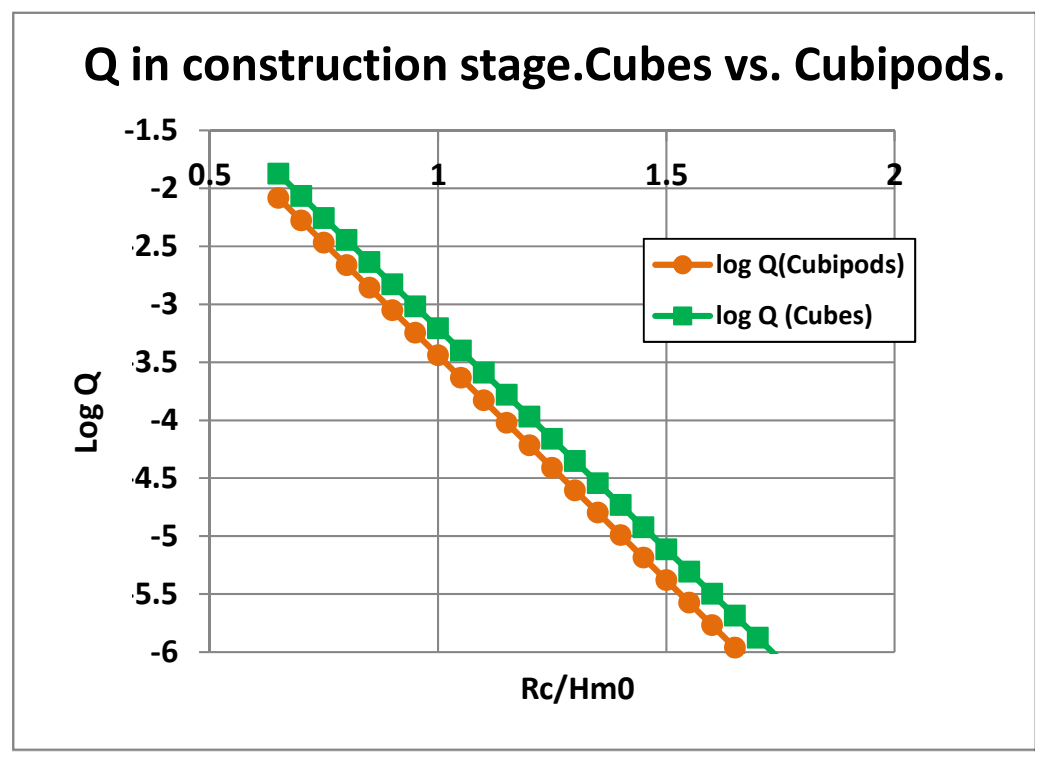

Figure 7. Cube and Cubipod overtopping in one section during construction.

The overtopping formula given by the EurOtop Manual (2007) for conventional sections was applied to the UPV tests (section during construction). Figure 8 compares cube overtopping rates predicted by the formula in the EurOtop Manual (2007) with those predicted by Equation 5. Red dots represent a value of $\mathrm{Rc} / \mathrm{d}=0.225$, near the usual range of fully constructed sections. In this case, the EurOtop Manual (2007) formula correctly estimated overtopping on a section under construction. Blue dots represent a value of $\mathrm{Rc} / \mathrm{d}=0.09$, far from the usual range. In this case, the formula given in EurOtop Manual (2007) did not correctly estimate overtopping rates for incomplete sections. Therefore, conventional overtopping formulas should be applied with caution when estimating overtopping rates during construction.

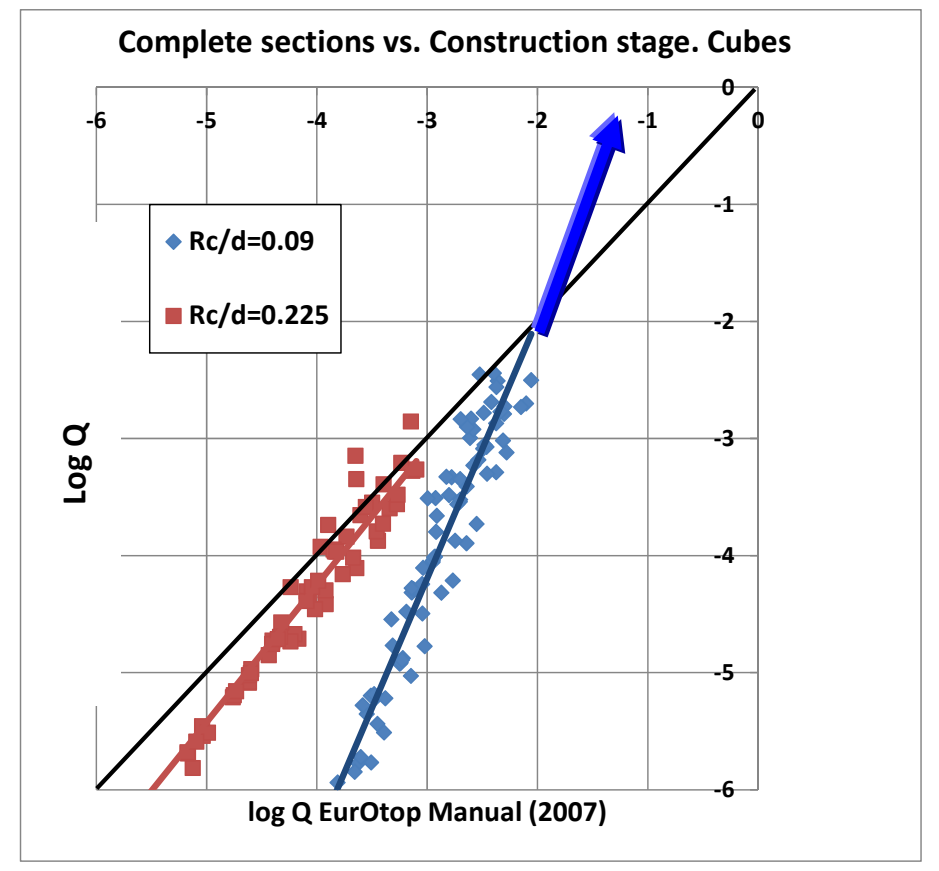

Figure 8. EurOtop (2007) overtopping prediction compared with new formulas (2-layer cube armor).

\section{CONCLUSIONS}

Low armor porosities are easy to achieve in laboratory tests; nevertheless, in real constructions porosity is quite difficult to control. Thus, structures built for small-scale tests may behave differently 
from real structures; low porosities involve higher hydraulic stability and can affect overtopping, wave reflection and run-up. Armor porosity is usually fixed during design without considering its influence on construction costs and hydraulic stability. Until now, armor porosity has not been fully analyzed in previous overtopping research. Its influence has generally been measured by the armor roughness factor, which depends on the CAU. In this research, small-scale tests at 1:46 scale were carried out to determine the influence of armor porosity on overtopping.

Results suggested that the higher the armor porosity, the greater the damage, especially in the case of cube armors. Tests results confirmed that armor porosity did not significantly affect overtopping discharges. While these small-scale tests were conducted to represent the standard construction porosities (37\%-46\% for cubes and $37 \%-42 \%$ for Cubipods), this range seems too small to properly assess the influence of porosity on overtopping. Note that totally face-to-face fitted cube armors, overtopping rates may even double those of cube armored breakwaters with $37 \%-40 \%$ porosity.

Results also revealed less overtopping on Cubipod than on cube armored breakwaters under similar wave conditions. Two new formulas (see Equations 5 and 6) were obtained to estimate overtopping for cube and Cubipod armored breakwaters under construction with RMSE $<16 \%$. The parameter Rc/d affected overtopping discharges, especially in a section during construction. Unlike conventional sections, incomplete sections feature deep armor layers, so Rc/d must be considered for overtopping studies of incomplete sections. Conventional formulas, such as those in the EurOtop Manual (2007), should be applied with caution to estimate overtopping on incomplete sections. When Rc/d is near the standard range, conventional formulas correctly estimate overtopping rates; however, when Rc/d is far from the standard range, conventional formulas can either underestimate or overestimate the overtopping discharges.

\section{ACKNOWLEDGEMENTS}

The authors received financial support from SATO and CDTI (Centro para el Desarrollo Tecnológico e Industrial). The authors thank Debra Westall for revising the manuscript. J. Molines was also supported through the FPU program (Formación del Profesorado Universitario) funded by the Spanish Ministry of Education (Ministerio de Educación, Cultura y Deporte)

\section{REFERENCES}

Aminti, P. and L. Franco. 1988. Wave overtopping on rubble mound breakwaters. Proc. $21^{\text {st }}$ ICCE, ASCE, 770-781.

Bruce, T., J.W. Van der Meer, L. Franco, and J.M. Pearson. 2009. Overtopping performance of different armour units for rubble mound breakwaters. Coastal Engineering, 56, 166- 179.

EurOtop Manual 2007. Wave Overtopping of Sea Defences and Related Structures: Assessment Manual. Environment Agency, Expertise Netwerk Waterkeren, Kuratorium für Forschung im Küsteningenieurwesen, 111-119.

Figueres, M. and J.R. Medina. 2004. Estimating incident and reflected waves using a fully nonlinear wave model. Proc. 29 $9^{\text {th }}$ ICCE, ASCE, 594-603.

Gómez-Martín, M.E. and J.R. Medina. 2006. Damage progression on cube armored breakwaters. Proc. $30^{\text {th }}$ ICCE, ASCE, 5229-5240.

Gómez-Martín, M.E. and J.R. Medina. 2007. Cubipod concrete armour unit and heterogeneous packing. Proc. Coastal Structures ‘07, World Scientific Publishing, 140-151.

Medina, J.R., J.A. González-Escrivá, J.M. Garrido, and J. de Rouk. 2002. Overtopping analysis using neural networks. Proc. $28^{\text {th }}$ ICCE, ASCE, 2165-2177.

Medina, J.R., M.E. Gómez-Martín, and A. Corredor. 2010. Influence of armor unit placement on armor porosity and hydraulic stability. Proc. $32^{\text {nd }}$ ICCE, ASCE, 5229-5240.

Shankar, N.J. and M.P.R. Jayaratne. 2003. Wave run-up and overtopping on smooth and rough slopes of coastal structures. Ocean Engineering, 30, 221-238.

Smolka, E., G. Zarranz, and J.R. Medina. 2009. Estudio Experimental del Rebase de un Dique en Talud de Cubípodos. Libro de Ponencias de las X Jornadas Españolas de Costas y Puertos, Universidad de Cantabria-Adif Congresos, 803-809.

SPM. 1984. Shore Protection Manual, U.S. Army Corps of Engineers, Waterways Experiment Station, Coastal and Hydraulics Laboratory, Vicksburg, MS. Volume III, 20-70. 